\title{
STUDIES ON LIPID METABOLISM IN THE SMALL INTESTINE WITH OBSERVATIONS ON THE ROLE OF BILE SALTS * $\dagger$
}

\author{
By ANTHONY M. DAWSON $\ddagger$ AND KURT J. ISSELBACHER WITH THE TECHNICAL \\ ASSISTANCE OF VIRGINIA M. BELL
}

(From the Department of Medicine, Harvard Medical School, and the Medical Services, Massachusetts General Hospital, Boston, Mass.)

(Submitted for publication October 27, 1959; accepted November 20, 1959)

It is now well established that the esterification of long chain fatty acids is an important step in their transport across the small intestinal mucosa before they appear in the lymph in chylomicrons. Evidence for this process has been well reviewed recently $(1,2)$. The main ester formed by the mucosa is triglyceride but a small proportion of the fatty acids is incorporated into phospholipids and cholesterol esters. We have recently reported some in vitro studies on the incorporation of long chain fatty acids into glycerides using homogenates of rat and human small intestine mucosa and have delineated some of the cofactor requirements involved (3). This work has now been extended to the intact mucosa of the rat. Observations are presented on factors influencing the uptake and esterification of palmitate-1-C ${ }^{14}$ and the incorporation of label into lipid from $\mathrm{C}^{14}$ glucose. In addition, evidence is presented for the concept that conjugated bile salts directly stimulate glyceride metabolism in the intestinal mucosa.

\section{MATERIALS AND METHODS}

Palmitic acid-1-C $\mathrm{C}^{14}$ and uniformly labeled glucose- $\mathrm{C}^{14}$ were obtained from the Volk Radiochemical Company, Chicago, Illinois. The $\mathrm{C}^{14}$-labeled palmitate was purified and made up into a solution as previously described (2). Crystalline bovine albumin was obtained from Nutritional Biochemicals Corporation, Cleveland, Ohio. Cholic acid and desoxycholic acid were obtained from Matheson, Coleman and Bell, Norwood, Ohio and the cholic acid was recrystallized from 70 per cent ethanol. The taurine derivatives of these acids and glycocholic acid were prepared according to Norman (4) and their

* Presented in part before the American Society for Clinical Investigation, Atlantic City, New Jersey, May, 1959.

$\dagger$ This work has been supported by a grant (A-3014) from the National Institutes of Health, Bethesda, Md.

$\ddagger$ Lederle Traveling Fellow of the Medical Research Council of Great Britain. Present address: Royal Free Hospital, London, W.C. 1, England. purity tested by melting point determinations and paper chromatography (5). Hydrolysis of the conjugated bile salts, glycocholate and taurodesoxycholate was carried out by dissolving them in $2 \mathrm{~N} \mathrm{NaOH}$ and then heating in sealed Pyrex tubes at $140^{\circ} \mathrm{C}$ for 3 hours. The resulting solution was diluted with water, acidified, and the precipitated free bile salt filtered, washed and dried. In earlier experiments commercial sodium taurocholate (Pfanstiehl Laboratory, Waukegan, Ill.) was used. This contained a faint trace of glycocholate which could only be demonstrated by chromatography when there was heavy overloading of Whatman no. 3 filter paper. No unconjugated bile salts were present but there were some contaminating pigments. The commercial taurocholate gave substantially the same results as the synthetic material which was used in later experiments.

Female albino rats (Charles River Laboratories, Boston, Mass.) weighing 150 to $250 \mathrm{~g}$ were fasted overnight. They were killed by a blow on the head and the small intestine washed out at room temperature with oxygenated Krebs-Ringer phosphate buffer, $\mathrm{pH} 7.4$, modified to contain half the usual concentration of calcium. This buffer was used in all the experiments described. The small intestine was everted on a glass rod following the technique of Wilson and Wiseman (6) and then cut across so as to form small cylindrical segments or intestinal rings. These measured approximately oneeighth inch (lengthwise) and weighed between 80 to $150 \mathrm{mg}$ (wet weight). Since one of the problems in using slices or sacs of small intestine in metabolic studies is the variation in activity along this organ, some preliminary experiments were performed to determine the distribution of esterifying activity along the intestine. It was found that under optimal conditions there was moderate (50 per cent) variation of activity along the upper four-fifths of the jejuno-ileum. The terminal ileum showed an abrupt and profound fall off in activity to 5 to 10 per cent that of the upper intestine. Colonic tissue was about as active as terminal ileum. Thus the reproducibility of our method was increased in subsequent studies by 1) using only the upper two-thirds of the jejuno-ileum, 2) by using at least two segments of intestine in each incubation flask with each segment coming from a different site, and 3) by performing all incubations in duplicate. Incubations were carried out in $25 \mathrm{ml}$ Erlenmeyer flasks and the incubation mixture contained either palmitate-1-C $\mathrm{C}^{14}$ or uniformly labeled glucose- $\mathrm{C}^{14}$ plus other agents such as bile salts, Tween " 80 " 
(polyoxyethylene sorbitan mono-oleate) and albumin as indicated in the individual experiments. The incubation mixture was made up to a volume of $4 \mathrm{ml}$ with buffer. All incubations were performed under oxygen at $25^{\circ} \mathrm{C}$ in a Dubnoff shaking incubator. It was found that incubating at $25^{\circ}$ as compared to $37^{\circ} \mathrm{C}$ reduced the transport of esterified lipid out of the tissue to less than 0.1 per cent [using the everted sac technique (6)] and thus increased the validity of simply analyzing tissue lipid at the end of the incubation. This temperature also permitted a better demonstration of the effects of bile salts on the system. At the end of the incubation the flasks were placed on ice and the intestinal segments washed in cold Krebs-Ringer buffer, blotted and weighed on a microtorsion balance. The method of extracting lipid from the tissue was based on that of Folch, Lees and Sloane Stanley (7). Segments were homogenized in chloroform-methanol $(2: 1)$ in a tissue grinder (PotterElvehjem, Teflon pestle) and the mixture allowed to stand at least 30 minutes at room temperature. It was then filtered through Whatman no. 1 filter paper into a $50 \mathrm{ml}$ Pyrex centrifuge tube which was fitted with a ground glass stopper. A volume of water was added which was approximately one-fifth of the chloroformmethanol solution. The mixture was shaken and the separation into two phases facilitated by centrifuging at $2,500 \mathrm{rpm}$ for 5 minutes. The upper aqueous methanol phase was drawn off and discarded. In experiments with radioactive palmitate the resulting chloroform solution was evaporated to dryness and the lipid, after being dissolved in $10 \mathrm{ml}$ of petroleum ether, was washed once with $20 \mathrm{ml}$ of $0.1 \mathrm{M} \mathrm{KCl}$ to remove any nonlipid radioactive metabolites. The total lipid radioactivity was assayed by counting $2 \mathrm{ml}$ of this petroleum ether extract in a lipid scintillation spectrometer (3). Duplicate tissue analyses agreed within 10 to 15 per cent. Another aliquot of the petroleum ether solution was evaporated to dryness in a lipped test tube, taken up in $2 \mathrm{ml}$ of wet ether and the unesterified fatty acids removed by passage through an Amberlite IRA-400 column. The ether eluate representing esterified lipid was evaporated, taken up in petroleum ether, and counted. In experiments with $\mathrm{C}^{\mathbf{1 4}}$ labeled glucose the chloroform solution containing the lipid was evaporated and the lipid taken up in $10 \mathrm{ml}$ of petroleum ether and washed three times with approximately $0.1 \mathrm{M} \mathrm{KCl}$ before counting an aliquot of the petroleum ether extract. Negligible water-soluble radioactivity remained in the petroleum ether under such conditions. In experiments where further fractionation of the lipid was to be performed by silicic acid chromatography, all evaporations were conducted under nitrogen, the samples were not heated to above $37^{\circ} \mathrm{C}$ and they were stored at $-10^{\circ} \mathrm{C}$ in tubes previously gassed with nitrogen.

Other methods and the preparations of materials have been described previously (3). Tissue from guinea pig, hamster and rabbit were prepared in a manner similar to that used for rat tissue. Human jejunal tissue was obtained at operation from patients undergoing partial gastrectomy and was immediately placed in oxygenated Krebs-Ringer buffer at room temperature and transported as quickly as possible to the laboratory for incubation. This process took less than 20 minutes.

\section{RESULTS}

Studies on binding versus esterification of palmitate-1-C $C^{14}$. When a slice of everted rat small intestine is incubated with only palmitate-1-C $\mathrm{C}^{\mathbf{1 4}}$ and buffer, there is a large uptake of labeled fatty acid by the tissue, but only a negligible proportion of this fatty acid is esterified. The addition of substances to the incubation medium which are known to maintain fatty acids in solution, such as albumin, Tween " 80 ," and taurocholate, decrease the total uptake of palmitate-1-C $\mathrm{C}^{\mathbf{1 4}}$ but significantly increase the amount which is esterified (Table I). Of these three agents taurocholate is by far the most effective. It seemed likely that the large uptake of radioactivity in the absence of one of these substances represented binding of the fatty acid to the cell surface. This possibility was investigated by examining the cellular distribution of the radioactivity in intestinal slices after an incubation. The results (Table II) indicate that in the absence of a wetting agent (taurocholate) most of the radioactivity was present in the cell debris, which contained cell walls and nuclei. This radioactivity was in the unesterified lipid fraction. These results were not significantly different when the incubation was performed under nitrogen or at $4^{\circ}$ rather than at $37^{\circ} \mathrm{C}$. On the other hand, when taurocholate was added to

TABLE I

The uptake and esterification of palmitate-1-C $C^{14}$ by slices of rat small intestine*

\begin{tabular}{|c|c|c|c|}
\hline \multirow[b]{2}{*}{ Additions $\dagger$} & \multicolumn{3}{|c|}{$\begin{array}{c}\text { Palmitate-1-C14/ } \\
100 \mathrm{mg} \text { tissue }\end{array}$} \\
\hline & Total & $\begin{array}{l}\text { Unester- } \\
\text { ified }\end{array}$ & $\begin{array}{l}\text { Ester- } \\
\text { ified }\end{array}$ \\
\hline & mumoles & mumoles & mumoles \\
\hline $\begin{array}{l}\text { None } \\
\text { Albumin }(5 \mathrm{mg} / \mathrm{ml}) \\
\text { Tween " } 80 "(0.38 \%) \\
\text { Taurocholate }\left(2 \times 10^{-2} \mathrm{M}\right)\end{array}$ & $\begin{array}{l}7.2 \\
4.8 \\
3.3 \\
5.7\end{array}$ & $\begin{array}{l}7.0 \\
4.2 \\
1.6 \\
1.0\end{array}$ & $\begin{array}{l}0.2 \\
0.6 \\
1.7 \\
4.7\end{array}$ \\
\hline
\end{tabular}

* All flasks contained in addition to substances listed above palmitate-1- $\mathrm{C}^{14}, 100 \mathrm{~m} \mu$ moles $\left(5 \times 10^{5} \mathrm{cpm}\right)$, and Krebs-Ringer phosphate buffer to a final volume of $4 \mathrm{ml}$. The incubation was for 1 hour at $25^{\circ} \mathrm{C}$.

$\dagger$ Figures in parentheses represent concentration in the incubation medium. 
TABLE II

The localization of palmitate-1-C $C^{14}$ in slices of rat small intestine *

\begin{tabular}{|c|c|c|c|c|c|c|c|}
\hline \multirow[b]{3}{*}{ Additions } & \multirow[b]{3}{*}{ Gas phase } & \multicolumn{6}{|c|}{ Palmitate-1-C14/100 mg tissue } \\
\hline & & \multicolumn{3}{|c|}{ Cellular debris $\dagger$} & \multicolumn{3}{|c|}{ Supernatant $\dagger$} \\
\hline & & Total & $\begin{array}{l}\text { Unester- } \\
\text { ified }\end{array}$ & $\begin{array}{l}\text { Ester- } \\
\text { ified }\end{array}$ & Total & $\begin{array}{l}\text { Unester- } \\
\text { ified }\end{array}$ & $\begin{array}{l}\text { Ester- } \\
\text { ified }\end{array}$ \\
\hline & & mumoles & mumoles & mumoles & mumoles & mumoles & mumoles \\
\hline $\begin{array}{l}\text { None } \\
\text { None } \\
\text { Taurocholate } \\
\left(2 \times 10^{-2} \mathrm{M}\right)\end{array}$ & $\begin{array}{l}\text { Oxygen } \\
\text { Nitrogen } \\
\text { Oxygen }\end{array}$ & $\begin{array}{r}22.9 \\
22.3 \\
6.6\end{array}$ & $\begin{array}{r}22.0 \\
21.8 \\
1.1\end{array}$ & $\begin{array}{l}0.9 \\
0.5 \\
5.5\end{array}$ & $\begin{array}{l}0.8 \\
0.6 \\
2.5\end{array}$ & $\begin{array}{l}0.6 \\
0.4 \\
0.2\end{array}$ & $\begin{array}{l}0.2 \\
0.2 \\
2.3\end{array}$ \\
\hline
\end{tabular}

* All flasks contained palmitate-1-C $\mathrm{C}^{14}, 100$ m mmoles $\left(5 \times 10^{5} \mathrm{cpm}\right)$, and Krebs-Ringer phosphate buffer in a final volume of $4 \mathrm{ml}$. The incubation was for 1 hour at $25^{\circ} \mathrm{C}$.

$\dagger$ Based on the centrifugation at $600 \times \mathrm{G}$ at $4^{\circ} \mathrm{C}$ of a $0.15 \mathrm{M} \mathrm{KCl}$ homogenate of the slices.

the incubation medium a considerable proportion of the radioactivity was present in the supernatant fraction and was esterified. Additional experiments with albumin and Tween " 80 " gave results similar to those with taurocholate. As would be expected from our previous studies on palmitate esterification (3), this process in the intestinal slices was energy-dependent. An energy requirement was shown by performing incubations with $2 \times 10^{-2} \mathrm{M}$ taurocholate anaerobically or in the presence of either dinitrophenol $\left(10^{-4} \mathrm{M}\right)$ or potassium fluoride $\left(2 \times 2^{-2} \mathrm{M}\right)$. These conditions resulted in inhibition of palmitate esterification (viz., 85, 96 and 64 per cent inhibition, respectively).

The effect of conjugated bile salts on the esterification of palmitate-1-C ${ }^{14}$. The conjugated bile salts studied were taurocholate, glycocholate and taurodesoxycholate and all stimulated the esterification of palmitate-1-C $\mathrm{C}^{14}$. The respective curves demonstrating the effect of increasing concen-

TABLE III

The additive effect of different bile salts on the esterification of palmitate-1- $C^{14}$ by slices of rat small intestine*

\begin{tabular}{|c|c|c|}
\hline \multicolumn{2}{|c|}{ Bile salt added } & \multirow{2}{*}{$\begin{array}{l}\text { Palmitate-1-C14 } \\
\text { esterified/ } \\
100 \mathrm{mg} \text { tissue }\end{array}$} \\
\hline Glycocholate & $\begin{array}{c}\text { Taurodesoxy- } \\
\text { cholate }\end{array}$ & \\
\hline$\underset{\mathrm{ml}}{\mathrm{\mu moles} / \mathrm{I}}$ & $\underset{\mathrm{ml}}{\boldsymbol{\mu m o l e s} /}$ & mumoles \\
\hline $\begin{array}{l}0 \\
5 \\
0 \\
5\end{array}$ & $\begin{array}{l}0 \\
0 \\
1 \\
1\end{array}$ & $\begin{array}{l}0.58 \\
0.64 \\
0.48 \\
3.4\end{array}$ \\
\hline
\end{tabular}

* Each flask contained palmitate-1-C ${ }^{14}, 100$ m $\mu$ moles $\left(5 \times 10^{5} \mathrm{cpm}\right)$, and Krebs-Ringer phosphate buffer to give a final volume of $4 \mathrm{ml}$. The incubation was for 1 hour at $25^{\circ} \mathrm{C}$. trations of these salts are shown in Figure 1. The cholate derivatives had an optimal concentration of 1.5 to $2 \times 10^{-2} \mathrm{M}$ while the optimal concentration for taurodesoxycholate was $5 \times$ $10^{-3} \mathrm{M}$. Higher concentrations of taurodesoxycholate inhibited the reaction. These curves also show that there was only negligible stimulation by the cholate derivatives below concentrations of $5 \times 10^{-3} \mathrm{M}$ and by taurodesoxycholate below $10^{-3} \mathrm{M}$. However, the addition of two bile salts (glycocholate and taurodesoxycholate), in concentrations at which each salt alone produced no effect, resulted in stimulation (Table III). The optimal activity of each of these three bile salts studied was comparable under our experimental conditions.

In view of the fact that rat bile contains predominantly taurocholate $(8-10)$ it was of interest to study the effect of this salt on tissue from species which predominantly have glycine-conjugated

TABLE IV

The effect of taurocholate on the esterification of palmitate-1-C14 by slices of small intestine of various species * $\dagger$

\begin{tabular}{lcc}
\hline \hline & \multicolumn{2}{c}{ Additions } \\
\cline { 2 - 3 } Species & None & $\begin{array}{r}\text { Taurocholate } \\
\left(2 \times 10^{-2} \mathbf{M}\right)\end{array}$ \\
\hline Guinea pig & 3.1 & 9.2 \\
Hamster & 6.1 & 27.6 \\
Human & 2.0 & 17.3 \\
Rabbit & 2.2 & 5.5 \\
Rat & 1.6 & 3.8 \\
\hline
\end{tabular}

* Results expressed as millimicromoles palmitate-1-C14 esterified per $100 \mathrm{mg}$ intestine, except human tissue which is per $100 \mathrm{mg}$ intestinal mucosa.

Each flask contained palmitate-1-C $14,100 \mathrm{~m} \mu$ moles $\left(5 \times 10^{5} \mathrm{cpm}\right), 20 \mathrm{mg}$ of albumin and Krebs-Ringer phosphate buffer to a final volume of $4 \mathrm{ml}$. The incubation was for 1 hour at $25^{\circ} \mathrm{C}$. 
TABLE V

Comparison of the effect of Tween " 80 " and taurocholate on the esterification of palmitate-1-C14 by slices of rat small intestine *

\begin{tabular}{ccc}
\hline \hline Tween "80" & Taurocholate & $\begin{array}{c}\text { Palmitate-1-C14 } \\
\text { esterified/ } \\
100 \text { mg tissue }\end{array}$ \\
\hline$\%$ & $\mu$ moles $/ m l$ & mumoles \\
0.38 & None & 1.2 \\
0.5 & None & 1.1 \\
0.38 & 20 & 4.2 \\
None & 20 & 4.6
\end{tabular}

* Each flask contained palmitate-1-C ${ }^{14}, 100 \mathrm{~m} \mu$ mole $s$ $\left(5 \times 10^{5} \mathrm{cpm}\right)$, and Krebs-Ringer phosphate buffer to give a final volume of $4 \mathrm{ml}$. The incubation was for 1 hour at $25^{\circ} \mathrm{C}$.

bile salts (hamster, rabbit and guinea pig) and from those which excrete a more equal mixture of glycine and taurine conjugates (man) (8-10). In all these species taurocholate $\left(2 \times 10^{-2} \mathrm{M}\right)$ stimulated the esterification of palmitate-1-C ${ }^{14}$ (Table IV).

Since both taurocholate and Tween " 80 " are good emulsifying agents, the observation in Table I that taurocholate was 2.5 times as effective as Tween " 80 " in stimulating the esterification of palmitate was further investigated. The results in Table $\mathrm{V}$ demonstrate that at optimal taurocholate concentrations the addition of Tween " 80 " had no effect. In contrast, at optimal Tween " 80 " concentrations the addition of taurocholate produced a further stimulation (fourfold). The fact that taurocholate was more effective than
Tween " 80 " in stimulating the esterification of palmitate-1-C ${ }^{14}$ suggested that taurocholate might have another role besides that of an intraluminal emulsifier of fat. It seemed probable that if taurocholate were merely acting as an emulsifying agent, preincubation of small intestine for $30 \mathrm{~min}$ utes with taurocholate, before the addition of palmitate-1-C ${ }^{14}$, would offer no advantage over control tubes preincubated with buffer only. However, if taurocholate also had a cellular effect, preincubation with the bile salt might stimulate palmitate esterification. Such experiments were performed with taurocholate, glycocholate and taurodesoxycholate and compared to the action of a wetting agent such as Tween " 80 ". Table VI demonstrates that preincubation with these bile salts resulted in stimulation of palmitate esterification while Tween " 80 " had no such effect.

The effect of conjugated bile salts on the incorporation of label into lipid from glucose-1-C $C^{14}$. Further evidence that conjugated bile salts stimulate lipid metabolism in the mucosal cell is afforded by experiments using $\mathrm{C}^{14}$-labeled glucose. We have observed that when everted rat small intestine is incubated with a tracer amount of uniformly labeled $\mathrm{C}^{\mathbf{1 4}}$-glucose, a significant proportion of the radioactivity is incorporated into the tissue lipid (Table VII). Following saponification of such lipids a large proportion (i.e., greater than 95 per cent) of the radioactivity is in the water-soluble fraction, presumably in gly-

TABLE VI

The effect of preincubating slices of rat small intestine with conjugated bile salts and Tween "80" upon the esterification of palmitate-1-C $14 *$

\begin{tabular}{|c|c|c|c|c|c|c|}
\hline \multirow[b]{3}{*}{ Addition } & \multirow{3}{*}{$\begin{array}{l}\text { No. of } \\
\text { Expt. }\end{array}$} & \multicolumn{4}{|c|}{ Palmitate esterification/100 $\mathrm{mg}$ tissue after preincubation with } & \multirow{3}{*}{$\begin{array}{c}\text { Mean } \\
\text { change in } \\
\text { palmitate } \\
\text { esterification }\end{array}$} \\
\hline & & \multicolumn{2}{|c|}{ Buffer only } & \multicolumn{2}{|c|}{ Buffer plus wetting agent } & \\
\hline & & Mean & Range & Mean & Range & \\
\hline & & \multicolumn{2}{|c|}{ mumoles } & \multicolumn{2}{|c|}{ mumoles } & $\%$ \\
\hline $\begin{array}{l}\text { Taurocholate } \\
\left(10^{-2} \mathrm{M}\right)\end{array}$ & 6 & 1.1 & $0.7-1.5$ & 1.9 & $1.0-2.4$ & +71 \\
\hline $\begin{array}{l}\text { Glycocholate } \\
\left(10^{-2} \mathrm{M}\right)\end{array}$ & 6 & 1.2 & $0.9-1.7$ & 1.8 & $1.6-2.6$ & +45 \\
\hline $\begin{array}{l}\text { Taurodesoxycholate } \\
\left(1.5 \times 10^{-3} \mathrm{M}\right)\end{array}$ & 2 & 0.18 & $0.16-0.20$ & 0.30 & $0.28-0.32$ & +66 \\
\hline $\begin{array}{l}\text { Tween " } 80 \text { " } \\
(0.1 \%)\end{array}$ & 4 & 0.43 & $0.28-0.60$ & 0.40 & $0.24-0.61$ & -7 \\
\hline
\end{tabular}

* Control slices were preincubated in Krebs-Ringer phosphate buffer (column 3) and experimental slices with buffer plus bile salt or Tween " 80 " (column 4). After 30 minutes, palmitate-1-C14 (100 m $\mu$ moles) was added to both, as well as bile salts or Tween " 80 " to the controls in order to make the final concentration of the wetting agents equal in each set of flasks. Incubation was then carried out for 30 minutes. 
TABLE VII

The effect of taurocholate on $C^{14}$-glucose metabolism by rat small intestine *

\begin{tabular}{ccc}
\hline \hline Addition & \multicolumn{2}{c}{ Radioactivity/100 mg tissue } \\
\cline { 2 - 3 } & Total lipid & $\begin{array}{c}\text { Barium- } \\
\text { ethanol ppt. }\end{array}$ \\
\hline None & $c p m$ & $c p m$ \\
Taurocholate & 4,160 & 3,430 \\
$\left(2 \times 10^{-2} \mathrm{M}\right)$ & 16,400 & 3,360 \\
& & \\
\hline
\end{tabular}

* Each flask contained uniformly labeled glucose, 0.02 $\mu$ moles $\left(5 \times 10^{5}\right) \mathrm{cpm}$, and Krebs-Ringer phosphate buffer to give a final volume of $4 \mathrm{ml}$. The incubation was for 1 hour at $25^{\circ} \mathrm{C}$. After incubation the tissue was washed weighed and then homogenized in $0.15 \mathrm{M} \mathrm{KCl}$. One aliquot was used for lipid analysis. To another aliquot 1 $\mu$ mole of carrier fructose-1,6-diphosphate was added and the phosphorylated carbohydrates precipitated with barium and ethanol (11), plated on aluminum planchets and counted in a gas-flow counter. Correction was made for the different counting efficiency of the liquid scintillation spectrometer and the gas-flow counter. Each result is a mean of triplicate determinations.

cerol. The presence of taurocholate $\left(2 \times 10^{-2} \mathrm{M}\right)$ in the medium increases the incorporation of radioactivity into the lipid up to fourfold (Table VII). Such an increase in the radioactivity in tissue lipid could possibly result from an increased labeling of the intracellular glucose pool, secondary to a greater transport of the tracer glucose into the cell. If this were the explanation, one would also expect an increase in the labeling of other products of glucose metabolism, such as phosphorlylated carbohydrate intermediates. The phosphorylated carbohydrate intermediates were therefore isolated by barium-ethanol precipitation (11) and did not show any increase in radioactivity when taurocholate was present in the incubation medium (Table VII). Glycocholate and taurodesoxycholate also stimulated the incorporation of radioactivity into lipid when rat small intestine was incubated with $\mathrm{C}^{14}$-labeled glucose. The effect of varying concentrations of these salts on this process is shown in Figure 2. A comparison of the two sets of curves in Figures 1 and 2 shows that the optimal concentration for each bile salt was similar for both the labeled palmitate and labeled glucose experiments.

The formation of glycerol-labeled lipid from $\mathrm{C}^{14}$-labeled glucose in our experiments lends support to the hypothesis that glucose is a glycerideglycerol precursor in the mucosal cell during fatty acid absorption $(12,13)$. This was further sub- stantiated by observing a twofold increase of label in tissue lipid when $1 \mu$ mole of unlabeled palmitate was added to the $\mathrm{C}^{14}$-glucose incubation mixture under conditions optimal for the esterification of palmitate (vide supra).

The effect of unconjugated bile salts. In order to assess the role of the conjugation of bile salts, we investigated the effect of free bile salts on the small intestine. Specifically, we investigated the influence of cholate and desoxycholate on palmitate esterification, glucose transport and tissue histology. Free desoxycholate inhibited palmitate esterification (Figure 3 ), and this inhibition was demonstrable at a concentration as low as $5 \times 10^{-4} \mathrm{M}$ and was almost complete at $3 \times 10^{-3}$ M. This inhibition was more readily demonstrated when palmitate esterification had been increased by the presence of a wetting agent (e.g., albumin, Tween " 80 " or taurocholate). The inhibition by free desoxycholate is in striking contrast to the stimulation by taurodesoxycholate which occurs at an optimal concentration of $5 \times$

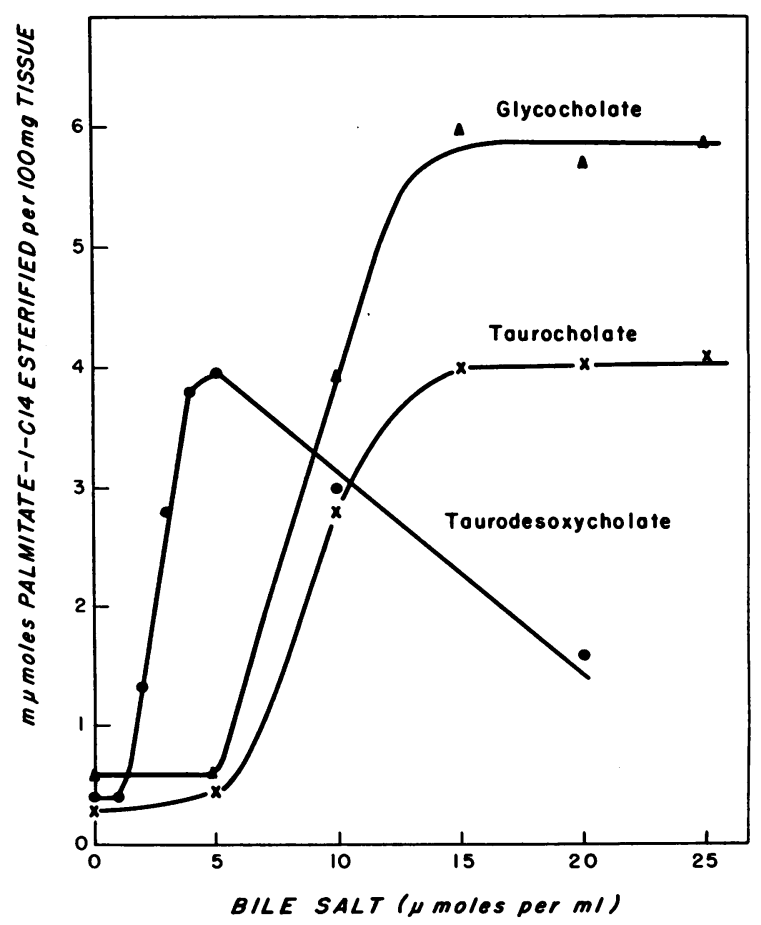

Fig. 1. The effect of conjugated bile salts on the ESTERIFICATION OF PALMITATE-1-C $C^{14}$ BY SLICES OF RAT SMALL INTESTINE. Standard incubation procedure was used. There were $100 \mathrm{~m} \mu$ moles $\left(5 \times 10^{5} \mathrm{cpm}\right)$ of palmitate-1- $\mathrm{C}^{14}$ in each flask and bile salts $\overline{\mathrm{s}}$ were added as indicated. 


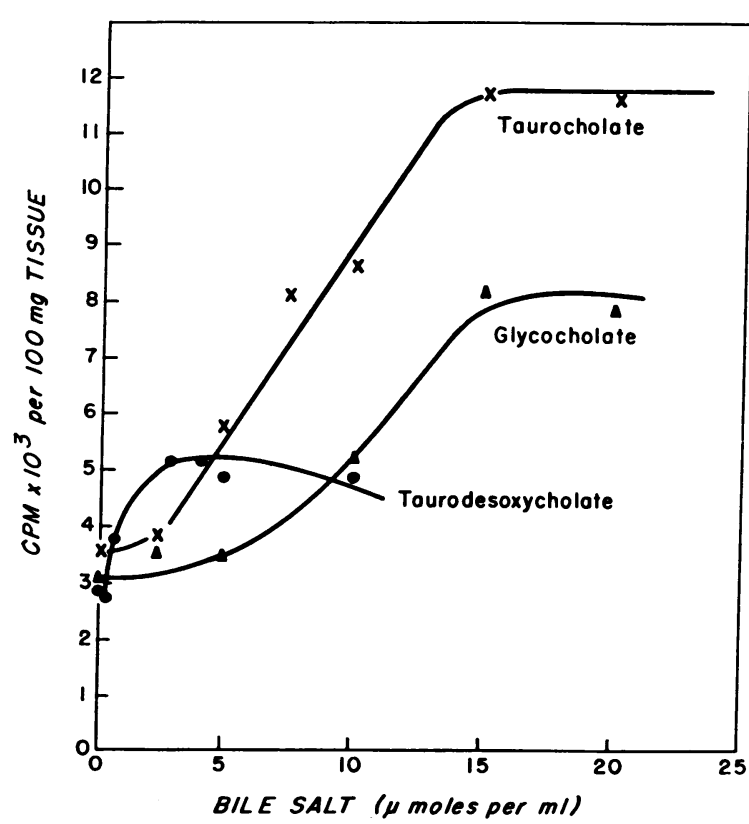

Fig. 2. The effect of Conjugated bile salts on the INCORPORATION OF RADIOACTIVITY FROM $\mathrm{C}^{14}$-GLUCOSE BY SLICES OF RAT SMALL INTESTINE. Each flask contained uniformly labeled $\mathrm{C}^{14}$-glucose, $0.1 \mu$ mole $\left(2.7 \times 10^{5} \mathrm{cpm}\right)$, and conjugated bile salts as indicated.

$10^{-3} \mathrm{M}$ (Figure 1). Free cholate, on the other hand, did not inhibit esterification and when its effects were compared to those of its conjugated

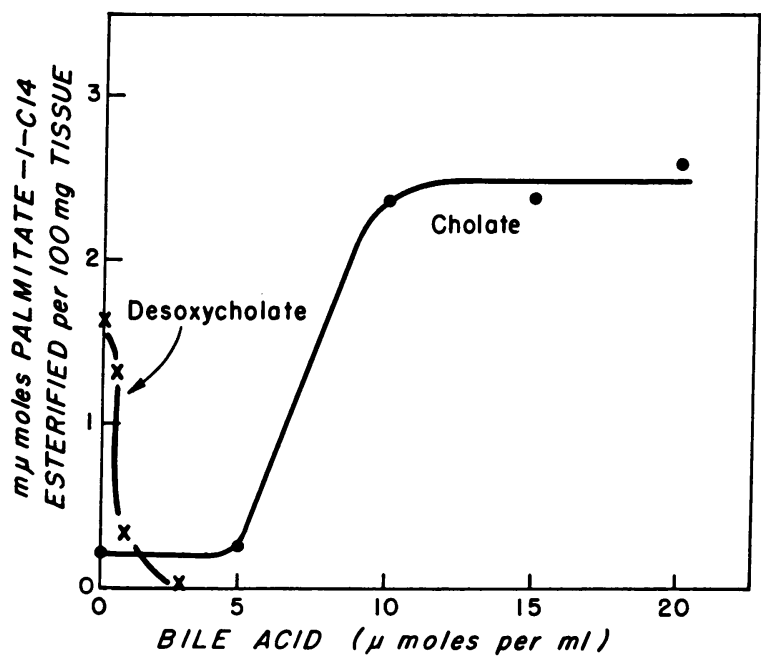

Fig. 3. The efFect of free bile salts on the esTERIFICATION OF PALMITATE-1-C ${ }^{14}$ BY SLICES OF RAT SMALL INTESTINE. Standard incubation conditions were used.

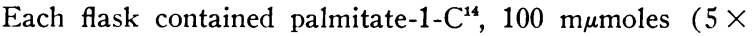
$\left.10^{5} \mathrm{cpm}\right)$, and free bile salts as indicated. Each flask in the desoxycholate experiments contained Tween "80" ( 0.38 per cent $)$ to facilitate esterification.
TABLE VIII

Comparison of the effect of cholate and its conjugated derivatives on the esterification of palmitate-1- $C^{14}$ by slices of rat small intestine *

\begin{tabular}{|c|c|c|}
\hline \multicolumn{2}{|c|}{ Bile salt } & \multirow{2}{*}{$\begin{array}{c}\text { Maximal } \\
\text { palmitate-1-C14 } \\
\text { esterified/ } \\
100 \mathrm{mg} \text { tissue }\end{array}$} \\
\hline Type & $\begin{array}{c}\text { Optimal } \\
\text { concentration }\end{array}$ & \\
\hline & $\times 10^{-3} \mathrm{M}$ & mumoles \\
\hline $\begin{array}{l}\text { Cholate } \\
\text { Glycocholate }\end{array}$ & $\begin{array}{l}10 \\
15\end{array}$ & $\begin{array}{l}2.8 \\
3.9\end{array}$ \\
\hline Taurocholate & 15 & 3.7 \\
\hline
\end{tabular}

* Standard incubation procedure. Data in column 2 are derived from Figures 1 and 3. Data in column 3 are derived from the action of the bile salts on tissue from the same rat.

derivatives (Table VIII, Figures 1 and 3 ) there were two obvious differences: 1) the maximal palmitate esterification produced by cholate was less than that produced by its conjugate when tested on tissue from the same animal (Table VIII, column 3); and 2) the concentration at which this maximum was reached was lower for cholate (Table VIII, column 2). To be certain that these observations were not due to unrecognized contaminants, these results were confirmed

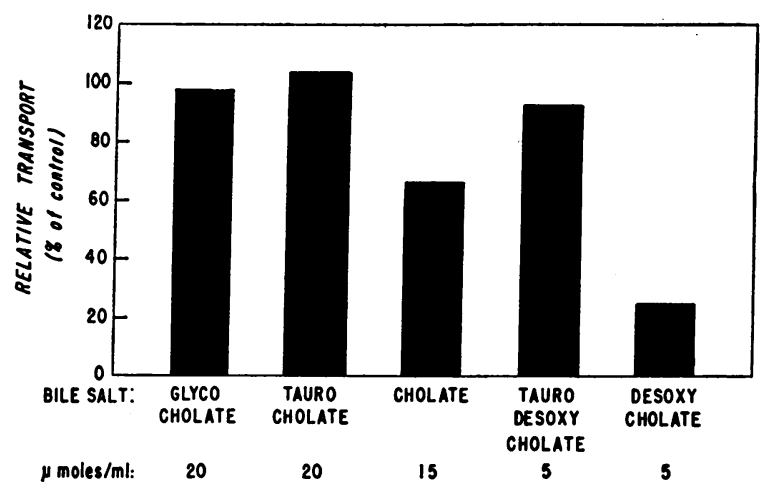

Fig. 4. THE EFFECT OF BILE SALtS ON THE TRANSPORT OF THE $\mathrm{C}^{14}$-GLUCOSE BY EVERTED SACS OF RAT SMALL INTESTINE. Krebs-Ringer phosphate buffer containing unlabeled glucose $\left(10^{-3} \mathrm{M}\right)$ was used for the incubation medium and for the sac contents. A tracer dose of $\mathrm{C}^{14}$ glucose $\left(0.02 \mu\right.$ mole, $\left.2.25 \times 10^{5} \mathrm{cpm}\right)$ was added to the incubation medium. Bile salts were added as indicated. The final volume of the incubation medium was $4 \mathrm{ml}$ and the incubation was for one hour at $25^{\circ} \mathrm{C}$ under oxygen. At the end of the incubations, aliquots of the sac contents were dried on planchets and counted in a gasflow counter. The control sacs without bile salts contained on an average $6.5 \times 10^{3} \mathrm{cpm}$ per $\mathrm{ml}$ at the end of the incubation. The results of the incubation with bile salts are expressed as per cent of the controls. Each result represents the mean value of at least eight sacs. 
with free acids obtained by the hydrolysis of recrystallized conjugated bile salts.

The inhibition by desoxycholate was not specific for the esterifying activity of the mucosa as shown by experiments on glucose transport using everted sacs of small intestine. It was found (Figure 4) that whereas taurodesoxycholate $\left(5 \times 10^{-3} \mathrm{M}\right)$ had no effect on glucose transport, free desoxycholate at this concentration decreased glucose transport by 75 per cent. Cholate $(1.5 \times$ $\left.10^{-2} \mathrm{M}\right)$ inhibited glucose transport 35 per cent, while its conjugated derivatives, glycocholate and taurocholate $\left(2 \times 10^{-2} \mathrm{M}\right)$, had no effect on this process. These results on the interference of intestinal glucose transport by free bile salts emphasize the limitation of using $\mathrm{C}^{14}$-glucose to assess intracellular metabolism when the results depend upon the initial entry of the label into the cell.

Normally, at the end of a one hour incubation of rat small intestine at $25^{\circ} \mathrm{C}$ in buffer containing glucose $\left(10^{-3} \mathrm{M}\right)$, histological sections of this tissue showed generally well preserved villi with scattered mild mucosal damage. The results were similar when taurodesoxycholate $\left(5 \times 10^{-3} \mathrm{M}\right)$ was in the medium (Figure 5A). On the other hand, free desoxycholate $\left(5 \times 10^{-3} \mathrm{M}\right)$ caused dissolution of the tissue with loss of whole villi (Figure 5B). Even at concentrations of $10^{-3} \mathrm{M}$ all villi had necrotic tips. The effect of cholate was far less pronounced, but at $1.5 \times 10^{-2} \mathrm{M}$ it caused histological damage to all villi. Intestinal segments incubated with glycocholate or taurocholate $\left(2 \times 10^{-2} \mathrm{M}\right)$ were histologically the same

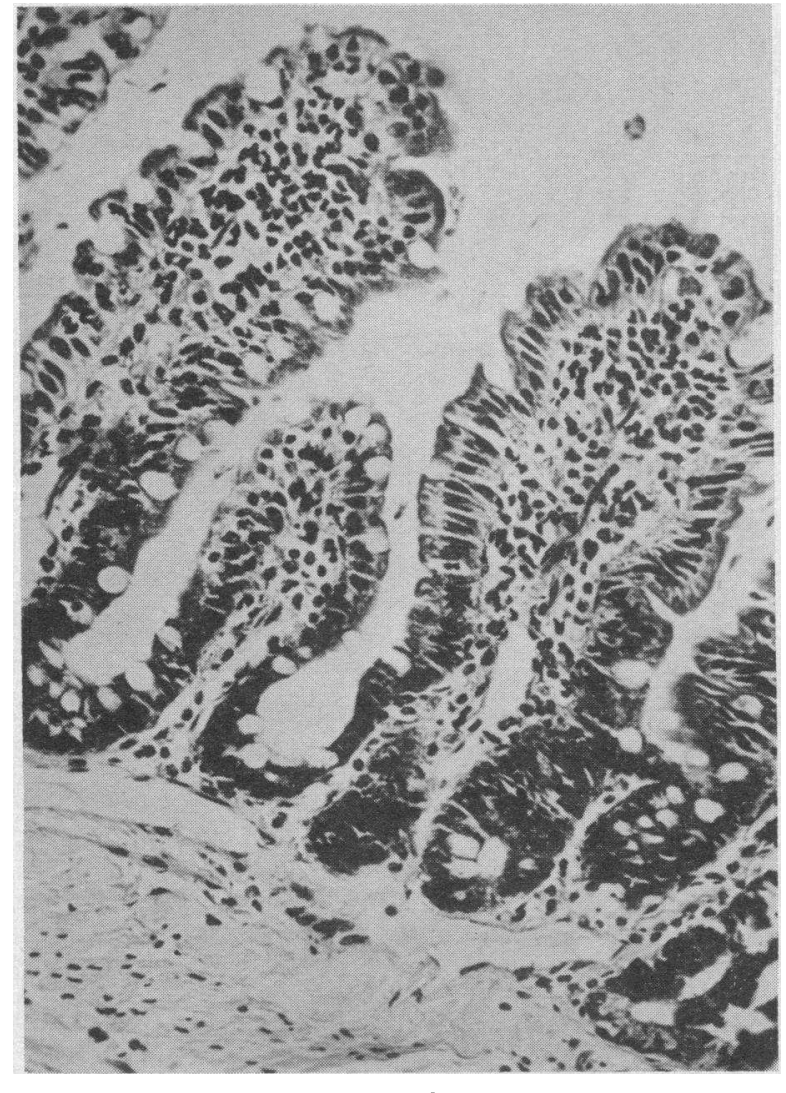

$\mathbf{A}$

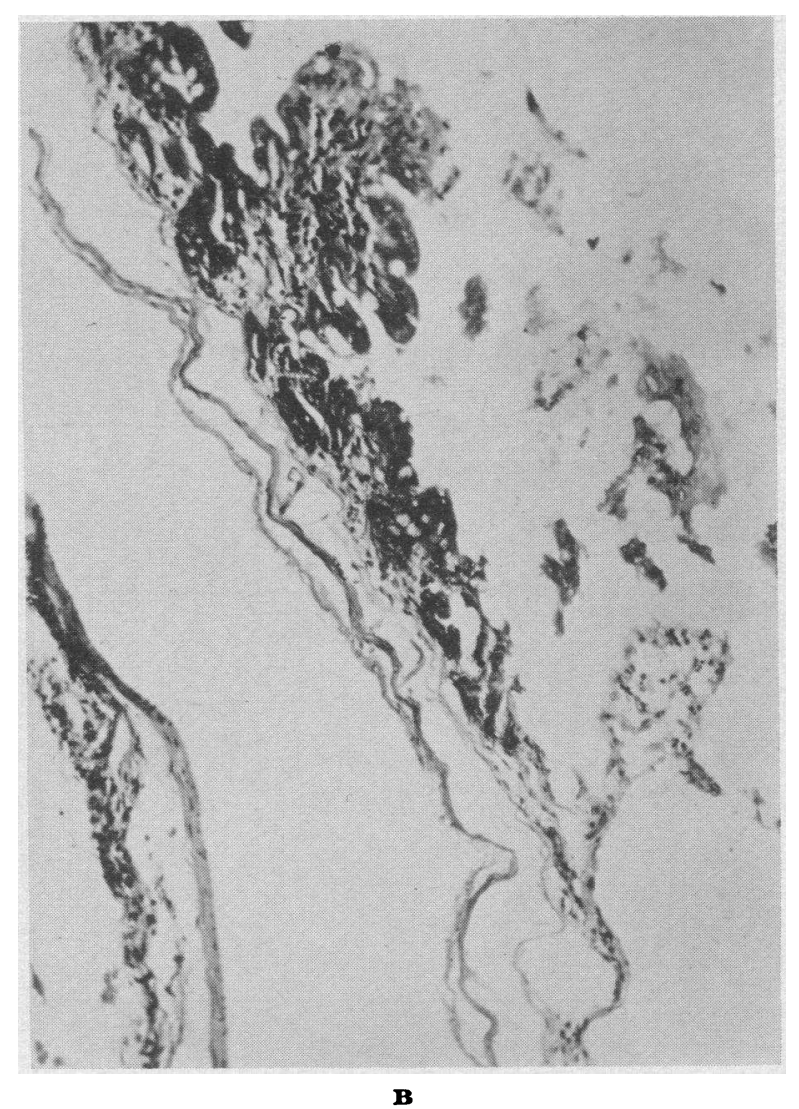

$\mathbf{B}$

Fig. 5. The efFect of FReE desoxycholate AND taURodesoxycholate in the histology of Rat SMALl INTESTINE. The sacs of small intestine used to demonstrate glucose transport (Figure 4) were fixed in 10 per cent formalin and histologic sections prepared and stained with hematoxylin and eosin. A) After incubation with taurodesoxycholate, $5 \times 10^{-3} \mathrm{M}$ (magnification $\times 200$ ) ; B) after incubation with desoxycholate, $5 \times 10^{-3} \mathrm{M}$ (magnification $\times 100)$. 
TABLE IX

The separation of labeled small intestinal lipids by silicic acid chromatography *

\begin{tabular}{|c|c|c|c|c|c|c|}
\hline \multicolumn{2}{|l|}{ Eluate } & \multirow{3}{*}{$\begin{array}{l}\text { Lipid fraction } \\
\text { eluted }\end{array}$} & \multicolumn{4}{|c|}{ Radioactive lipid following incubation with } \\
\hline \multirow[t]{2}{*}{ Solvent } & \multirow{2}{*}{$\frac{\text { Volume }}{m l \dagger}$} & & \multicolumn{2}{|c|}{ Palmitate-1-C } & \multicolumn{2}{|c|}{ C14-glucose } \\
\hline & & & $c p m$ & $\%$ & $c p m$ & $\%$ \\
\hline $1 \%$ Benzene & 18 & Cholesterol ester & 42 & 0.2 & & \\
\hline $3 \%$ Ether in hexane & 60 & Triglyceride & 19,846 & 86.8 & 23,913 & 92.0 \\
\hline $30 \%$ Ether in hexane & 60 & Diglyceride & 2,360 & 10.4 & 1,691 & 6.5 \\
\hline Ether & 60 & Monoglyceride & 224 & 1.0 & 200 & 0.7 \\
\hline Methanol & 100 & Phospholipid & 336 & 1.5 & 242 & 0.9 \\
\hline
\end{tabular}

* The lipid was prepared from rat small intestine following a standard incubation with either palmitate-1-C 14 or uniformly labled $\mathrm{C}^{14}$-glucose in the presence of taurocholate $2 \times 10^{-2} \mathrm{M}$. All extractions were performed under nitrogen and the lipid was not heated to more than $37^{\circ} \mathrm{C}$. The lipid from the glucose experiment was not passed through an Amberlite IRA-400 column prior to silicic acid chromatography.

$\dagger$ The eluate was collected in $6 \mathrm{ml}$ fractions and good separation of the respective lipid peaks was demonstrated. For the sake of brevity the total volume of each solvent fraction and the total radioactivity in each fraction are given.

as the controls. Similar experiments were also performed with everted segments of rat colon. The free bile salts again caused some mucosal damage but to a considerably lesser extent than that seen in the rat small intestine.

Identification of labeled incubation products. The results of silicic acid chromatography of the labeled lipid formed during an incubation with either palmitate-1- $\mathrm{C}^{14}$ or uniformly labeled $\mathrm{C}^{14}$ glucose are shown in Table IX. With labeled lipid derived from palmitate-1-C $\mathrm{C}^{14}$ experiments, 0.2 per cent of the counts were eluted with 1 per cent benzene in hexane and probably represented cholesterol ester. Over 85 per cent of the label was in the triglyceride fraction, about 10 per cent in the diglyceride fraction, and 1 to 2 per cent in both monoglyceride and phospholipid. In view of the very small proportion of counts in the lower glyceride fractions, their identity was also confirmed by chromatography on silicone impregnated paper (14). Some of the monoglyceride was found to come from hydrolysis of higher glycerides on the IRA- 400 column. The monoglyceride due to such hydrolysis amounted to 0.5 per cent of the total counts in the tri- and diglyceride fractions. Nevertheless, it is evident in Table IX that in the $\mathrm{C}^{14}$-glucose experiments (where IRA columns were not used) the labeled lipid still showed a definite, though small ( 0.7 per cent), monoglyceride fraction.

\section{DISCUSSION}

These observations on factors affecting lipid metabolism in rat small intestine have been facili- tated by using a reproducible technique for measuring both palmitate-1- $\mathrm{C}^{14}$ esterification and the incorporation of label from $\mathrm{C}^{14}$-glucose into intestinal lipid. A somewhat similar system for measuring palmitate esterification has recently been described by Johnston (15). He used everted sacs of hamster small intestine which were incubated at $37^{\circ} \mathrm{C}$ for 2.5 hours with a carefully prepared albumin-palmitate-1-C ${ }^{14}$ complex. Under his conditions, in contrast to our experiments, a significant proportion of esterified palmitate-1$\mathrm{C}^{14}$ was transported into the serosal medium. This difference may be related to the fact that he used a higher temperature, incubated for a longer time, and used a different species. From our observations the species difference is probably the most important, for Table IV shows that hamster jejunum is approximately seven times as active as that of the rat.

The observation that in the absence of a wetting agent palmitate-1- $\mathrm{C}^{14}$ adheres to the mucosal cell surface and that this process is not energy-dependent has been observed in other cells $(16,17)$. Goodman (16) found that red blood cells have a strong binding affinity for palmitate-1- $\mathrm{C}^{14}$ and that this property was also demonstrable with red cell ghosts or cyanide-poisoned cells. The reason for the negligible transport of palmitate into the mucosal cell, despite its adherence to the cell surface, is not known but was also described by Fillerup, Migliore and Mead (17) using ascites tumor cells. They facilitated the transport of palmitate into these cells by using an albuminpalmitate complex. In our system taurocholate and Tween " 80 " had this effect, as well as albu- 
min, which suggests that albumin acts by increasing the solubility of the fatty acid rather than by any other specific property. Johnston's observations that only 10 to 20 per cent of the palmitate$1-\mathrm{C}^{14}$ present in the tissue was unesterified may be explained by the fact that he used an albuminpalmitate complex in which all the palmitate was bound to the albumin. In our experiments not all the palmitate present was bound to albumin since we added the palmitate and albumin to the incubation medium for only 15 minutes before the tissue was added.

Bile salts are known to be of importance in fat absorption (10). Their postulated role is usually confined to that of a natural emulsifier of fat in the intestinal lumen. Their detergent action may or may not also explain their ability to activate pancreatic lipase (1). However, Verzar and McDougall (18) did suggest that bile salts might be of importance on the mucosal cell surface and Borgström (19), on the basis of balance studies in rats with bile and lymph fistulae, inferred that these salts had an intracellular function. Further evidence for such an action is that 24 hours after an injection of $\mathrm{C}^{14}$-labeled cholate the major portion of the label remaining in the tissues was present in the small intestinal mucosa (20).

In view of the fact that Tween " 80 " and albumin increase the esterification of palmitate-1- $\mathrm{C}^{\mathbf{1 4}}$ in our system, it was not surprising that bile salts which are also active surface agents would behave in a similar manner. But this cannot be the sole explanation of their effect. The preincubation experiments demonstrate that the conjugated bile salts tested, namely, taurocholate, glycocholate and taurodesoxycholate, have the property of stimulating the cellular phase of palmitate esterification. The site of such action might be on the cell surface, inside the cell or both. Recently pinocytosis has been described as an important mode of membrane transport for widely differing substances (21-24). The electron microscopic studies of Palay and Karlin (24) have suggested that pinocytosis is involved, at least in part, in the transport of fat across the rat small intestine following the feeding of corn oil. Pinocytosis may be stimulated by various factors in different tissues; e.g., insulin has been shown to induce pinocytosis in fat cells (23). It is possible that conjugated bile salts have an analogous effect on the intestinal mucosa and so stimulate the transport of palmitate into the cell making it available for esterification. Regardless of this highly speculative cellular surface role of conjugated bile salts, the experiments with $\mathrm{C}^{14}$-glucose show that these salts affect intramucosal lipid metabolism. A recent report by Whitehouse and Staple (25) provides further evidence that conjugated bile salts have an intracellular metabolic role.

It is of interest that at low concentrations these bile salts had no obvious effects. The observation that two conjugated bile salts can act in a complementary manner when present at low concentrations is of interest, for the bile of most species contains a mixture of these salts.

The difference between the biological properties of free bile salts and their conjugates has not been emphasized in the past, although pharmacological differences have been described (26). This difference was best demonstrated in our experiments by comparing the effect of taurodesoxycholate and desoxycholate on palmitate-1-C ${ }^{14}$ esterification, glucose transport, and tissue histology. The derangement in cell structure should perhaps not be surprising since this agent is frequently used to disrupt cell fractions in vitro (27). The difference between cholate and its conjugates was less impressive but nevertheless definite, especially with regard to the effect on glucose transport and cell structure. Whitehouse and Staple (25) also found that cholate and its conjugated derivatives differed in their metabolic effects in a cell-free system in that cholate inhibited pyruvate oxidation by rat liver mitochondria while its conjugated derivatives had no such effect.

Investigations on the physiology of absorption when crude bile salts are used must be interpreted with caution. Unless stringent tests of purity are employed the results may be misleading, for traces of unconjugated bile salts (especially desoxycholate) can alter mucosal function. We encountered this situation when testing both a crude ox bile preparation and a so-called "chemically pure" glycocholate preparation. Both substances contained free bile salts and both inhibited palmitate esterification. These findings might also partially explain some of the confusion concerning the therapeutic usefulness of bile salts 
in correcting impaired fat absorption in patients and rats with biliary fistulae.

The conjugation of bile salts which occurs in the liver immediately after they are synthesized from cholesterol serves to convert potentially harmful substances into physiologically useful ones. Normally the small intestine contains only conjugated bile salts. Some of these are absorbed by the small intestine while others pass into the large bowel where they are rapidly hydrolyzed and degraded by bacteria $(8,9,28)$.

In the clinical condition of intestinal "blind loops," it has been assumed that an altered small bowel flora contributes to the associated malabsorption (29). It is tempting to speculate that in circumstances where bacteria infest the small bowel conjugated bile salts may be converted in the lumen of the small intestine to toxic unconjugated derivatives. These products might then interfere with absorption, especially since it is known that one of the initial bacterial degradation products of cholate is desoxycholate.

In our analyses of the labeled lipid formed during an incubation, we consistently found a small proportion of the label ( 1 to 2 per cent) in the monoglyceride fraction. This monoglyceride fraction is of interest for it would not be expected as an intermediate in the formation of triglyceride from fatty acids if Kennedy's scheme for the conversion of fatty acids to neutral glycerides obtains in the mucosa (30). In fact the monoglyceride probably represents a product of lipolysis rather than of lipogenesis. Active mucosal lipolysis has been demonstrated in the rat in vivo (12) and in rat mucosal homogenates (3).

The action of the conjugated bile salts in the homogenate system (3) was different from that of the tissue slice. In the homogenate, taurocholate depressed the incorporation of palmitate-1-C ${ }^{\mathbf{1 4}}$ into neutral fat. This was interpreted as being due to the activation of lipase. The difference between the results using these two techniques probably is due to the abnormal structural relationships of cellular particles in the homogenate system. Thus, although homogenates are of use in delineating reactions and their cofactor requirements, the use of intact cells is mandatory to evaluate the possible physiological role of such reactions.

\section{SUMMARY}

1. A reproducible method has been described for studying aspects of lipid metabolism in slices of rat small intestine in vitro.

2. When slices of rat small intestine are incubated with only palmitate-1-C ${ }^{14}$ and buffer, fatty acid predominantly adheres to the cell surface and negligible esterification occurs. This binding is independent of the metabolic activity of the cell.

3. Esterification of palmitate by slices of intestine is facilitated by adding a wetting agent such as albumin, Tween " 80 " or taurocholate to the medium. This esterification is dependent upon the metabolic activity of the cell.

4. Conjugated bile salts stimulate the esterification of palmitate-1-C $\mathrm{C}^{\mathbf{1 4}}$ by directly affecting mucosal cell metabolism in addition to their effect on fatty acid solubility in the incubation medium. This was demonstrated by preincubation studies and by experiments in which conjugated bile salts stimulated the incorporation of radioactivity from $\mathrm{C}^{14}$-glucose into mucosal lipid.

5. The free bile salts, cholate and desoxycholate, behave differently from their conjugated derivatives. The free salts inhibit glucose transport by the small intestine and cause histological damage. Desoxycholate also inhibits palmitate esterification, but cholate stimulates this process. However, the stimulation of palmitate esterification by cholate is less than that produced by glycocholate or taurocholate.

6. Some possible physiological and pathological implications of these findings have been discussed.

\section{REFERENCES}

1. Bergström, S., and Borgström, B. The intestinal absorption of fats in Progress in the Chemistry of Fats and Other Lipids, R. T. Holman, W. O. Lundberg and T. Malkin, Eds. London, Pergamon Press Ltd., 1955, vol. 3, p. 351.

2. Ahrens, E. H., Jr., and Borgström, B. Fatty acid exchanges during fat digestion in the human intestine in Biochemical Problems of Lipids, G. Popják and E. LeBreton, Eds. Interscience Publishers, Inc., 1956, p. 315.

3. Dawson, A. M., and Isselbacher, K. J. The esterification of palmitate-1-C $\mathrm{C}^{14}$ by homogenates of intestinal mucosa. J. clin. Invest. 1959, 39, 150.

4. Norman, A. Preparation of conjugated bile acids using mixed carboxylic acid anhydrides. Ark. Kemi 1955, 8, 331. 
5. Sjövall, J. Separation of conjugated and free bile acids by paper chromatography. Bile acids and steroids 12. Acta. chem. scand. 1954, 8, 339.

6. Wilson, T. H., and Wiseman, G. The use of sacs of everted small intestine for the study of transference of substances from the mucosal to serosal surface. J. Physiol. (Lond.) 1954, 123, 116.

7. Folch, J., Lees, M., and Sloane Stanley, G. H. A simple method for the isolation and purification of total lipides from animal tissues. J. biol. Chem. 1957, 226, 497.

8. Bergström, S., and Borgström, B. Metabolism of lipides. Ann. Rev. Biochem. 1956, 25, 177.

9. Haslewood, G. A. D. Recent development in our knowledge of bile salts. Physiol. Rev. 1955, 35, 178.

10. Deuel, H. J. The Lipids. New York, Interscience Publishing Co., 1955, vol. 2, p. 69.

11. LePage, G. A. Methods for the analysis of phosphorylated intermediates in Manometric Techniques and Tissue Metabolism, W. W. Umbreit, R. H. Burris and J. F. Stauffer, Eds. Minneapolis, Minn., Burgess Publishing Co., 1951, p. 185.

12. Gidez, L. I., and Karnovsky, M. L. The metabolism of glyceride-glycerol. J. biol. Chem. 1956, 223, 293.

13. Buell, G. C., and Reiser, R. Glyceride-glycerol precursors in the intestinal mucosa. J. biol. Chem. 1959, 234, 217.

14. Schlenk, H., Gellerman, J. L., Tillotson, J. A., and Mangold, H. K. Paper chromatography of lipides. J. Amer. Oil Chem. Soc. 1957, 34, 377.

15. Johnston, J. M. The absorption of fatty acids by the isolated intestine. J: biol. Chem. 1959, 234, 1065.

16. Goodman, D. S. The interaction of human erythrocytes with sodium palmitate. J. clin. Invest. 1958, 37, 1729.

17. Fillerup, D. L., Migliore, J. C., and Mead, J. F. The uptake of lipoproteins by ascites tumor cells: The fatty acid-albumin complex. J. biol. Chem. 1958, 233, 98.

18. Verzar, F., and McDougall, E. J. Absorption from the Intestine. New York, Longmans, Green and Co., 1936.
19. Borgström, B. On the mechanism of the intestinal fat absorption. V. The effect of bile diversion on fat absorption in the rat. Acta physiol. scand. 1953, 28, 279.

20. Bergström, S., Rottenberg, M., and Sjövall, J. Über den Stoffwechsel der Cholsäure und Desoxycholsäure in der Ratte. Hoppe-Seylers Z. physiol. Chem. 1953, 295, 278.

21. Hampton, J. C. An electron microscope study of the hepatic uptake and excretion of submicroscopic particles injected into the blood stream and into the bile duct. Acta Anat. 1958, 32, 262.

22. Clark, S. L., Jr. The ingestion of proteins and colloidal materials by columnar absorptive cells of the small intestine in suckling rats and mice. J. biophys. biochem. Cytol. 1959, 5, 41.

23. Barrnett, R. J., and Ball, E. G. Morphologic and metabolic changes produced in rat adipose tissue in vitro by insulin (abstract). Science 1959, 129, 1282.

24. Palay, S. L., and Karlin, L. J. An electron microscopic study of intestinal villus. II. Pathway of fat absorption. J. biophys. biochem. Cytol. 1959, 5, 373.

25. Whitehouse, M. W., and Staple, E. Regulation of cholesterol oxidation by the liver in vitro. Proc. Soc. exp. Biol. (N. Y.) 1959, 101, 439.

26. Meyer, A. E., and McEwen, J. P. Bile acids and their choline salts applied to the inner surface of the isolated colon and ileum of the guinea pig. Amer. J. Physiol. 1948, 153, 386.

27. Palade, G. E., and Siekevitz, P. Liver microsomes, an integrated morphological and biochemical study. J. biophys. biochem. Cytol. 1956, 2, 171.

28. Norman, A., and Sjövall, J. On the transformation and enterohepatic circulation of cholic acid in the rat: Bile acids and steroids 68 . J. biol. Chem. 1958, 233, 872.

29. Badenoch, J. The blind loop syndrome in Modern Trends in Gastroenterology, F. Avery Jones, Ed. New York, Paul Hoeber, Inc., 1958, 2nd series, p. 231.

30. Kennedy, E. P. Metabolism of lipides. Ann. Rev. Biochem. 1957, 26, 119. 